\title{
Laju Pemampatan Tanah Gambut melalui Pengujian Konsolidasi Primer
}

\author{
(Studi Kasus : Tanah Gambut, Desa Tanjung Leban, Propinsi Riau) \\ (The Compression Rate of Peat Soil on Primary Consolidation Test \\ Case Study: Peat Soil from Tanjung Leban, Riau Province)
}

\author{
Efan Tifani ${ }^{1 *}$ \\ ${ }^{1}$ Jurusan Teknik Sipil Poloteknik Negeri Bengkalis \\ Jl. Bathin Alam, Sungai Alam, Bengkalis, Riau, Indonesia 28751 \\ *Penulis korespondensi: efantifani@polbeng.ac.id
}

Diterima: 16 Mei 2019

Disetujui: 25 Juni 2019

\begin{abstract}
This paper discussed the primary consolidation test of very soft soil in several loading and unloading combination. The very soft soil such as peat is easily compressed and thick. The initial loading of soft soil has required the preloading, which is the first loading of the soil to increase the bearing capacity and reduce the settlement in the primary consolidation before permanent construction of civil buildings is carried out. Based on this condition, it is necessary to carry out a primary consolidation test using an oedometer to determine the rate of compression of the peat soil and consolidation occurs using the square root of time method. Testing of the peat soil compression rate is carried out as much as 6 times of loading and 2 times of unloading in based on $\gamma_{\text {dmaks }}$ and optimum moisture content (OMC) conditions. The result of this study found that the compression that occurs in peat soil is substantial at the beginning of loading, then the compression is smaller in stage during 6 times of loading, this shows that peat soil has a very high compression and compressibility rate at the beginning of loading at time t90 with the resulting curve linear.
\end{abstract}

Keywords: Peat Soil, Compression, Loading Unloading, Consolidation

\section{PENDAHULUAN}

Tanah gambut terbentuk dari proses pelapukan dan pembusukan bahan organik dalam kondisi tergenang air (Kementrian Pertanian, 2016; W. S. Sidik dkk, 2014; H. Canakci dkk, 2016).Tanah gambut memiliki nilai kandungan organik yang tinggi, nilai angka pori dan porositas yang besar serta kandungan air yang tinggi menyebabkan tanah tersebut mudah mengalami pemampatan (N. E. Mochtar dan F. E. Yulianto, 2018). Pada umumnya pemampatan tanah gambut akibat pembebanan yang terjadi bukan disebabkan oleh konsolidasi primer seperti pada tanah lempung, akan tetapi disebabkan oleh penurunan segera (immediate settlement). Jika dilihat pada lokasi tertentu tentang perilaku penurunan tanah gambut di lapangan, tepatnya di Desa Tanjung Leban, Kecamatan Bukit Batu, Propinsi Riau, maka sebagian besar tanah gambut di lokasi tersebut tidak hanya mengalami immediate settlement setelah dibebani, hal ini dibuktikan masih adanya kandungan air yang tersimpan di dalam pori-pori tanah gambut dan masih memungkinkan untuk terjadinya konsolidasi primer. Berdasarkan kondisi tersebut maka dilakukan penelitian yang berbasis pengujian konsolidasi di laboratorium untuk mengetahui laju pemampatan dengan menggunakan tanah 
gambut dari Desa Tanjung Leban.

Porositas tanah gambut relatif tinggi umumnya berkisar 70\%-95\%, nilai porositas yang besar menunjukan nilai koefisien permabilitas yang besar (Sukandarrumidi, 2009). Menurut Mac Farlene (1995), daya rembes awal yang tinggi pada tanah gambut menyebabkan pemampatan awal yang terjadi sangat cepat. Pemampatan primer terjadi setelah tanah gambut dibebani. Hal ini didukung oleh hasil penelitian Christiansen dan $\mathrm{Wu}$ (1964) yang menyatakan bahwa ikatan yang lemah dan selaput air antara partikel akan menyebabkan deformasi plastik awal, yang selanjutnya diikuti oleh rangkak (creep) yang signifikan saat terjadi penurunan. Proses deformasi akibat hancurnya struktur pada serat-serat tanah gambut menyebabkan perilaku pemampatannya lebih rumit (Yenni 2008). Selain itu serat dan sisa tumbuhan biasanya memiliki orientasi horizontal sehingga material ini bersifat anisotropis.

Konsolidasi adalah proses berkurangnya volume atau berkurangnya rongga pori dari tanah jenuh berpermeabilitas rendah akibat adanya pembebanan. Proses tersebut dipengaruhi oleh kecepatan terperasnya air pori (terdisipasi) yang keluar dari pori-pori tanah sampai benar-benar hilang (hidrostatis) yang diikuti oleh kenaikan tegangan total pada tanah. (Hardiyatmo, 2010).

Penelitian terkait Pemampatan tanah gambut telah banyak dilakukan, diantaranya oleh Yenni (2008) yang melakukan penelitian mengenai perilaku kompresibilitas (pemampatan) tanah gambut dengan metode log-time pada kondisi dengan variasi kadar air tertentu, sedangkan dalam penelitian ini pemampatan tanah gambut dilakukan dengan metode akar waktu (square root of time method) pada kondisi $\gamma_{d}$ maks dan $O M C$ (dari pengujian pemadatan standar).
Adapun parameter $\gamma_{d \text { maks }}$ dan $O M C$ telah didapatkan dari data pengujian oleh Tifani (2015).

\section{METODOLOGI}

Penelitian yang dilakukan untuk mendapatkan laju pemampatan tanah gambut, melalui pengujian konsolidasi primer dan pembuatan grafik pemampatan tanah gambut dengan metode akar waktu (square root of time method).

\section{Pengujian Konsolidasi Primer}

Pengujian konsolidasi primer dilakukan dengan menggunakan alat oedometer, yang dilakukan sebanyak 6 kali pembebanan (loading) pada tegangan 0,$25 ; 0,50 ; 1,00 ; 2,00 ; 4,00 ; 8,00 \mathrm{~kg} / \mathrm{cm}^{2}$ dan sebanyak 2 kali pelepasan beban (unloading) pada tegangan 2,00 dan 0,25 $\mathrm{kg} / \mathrm{cm}^{2}$ pada kondisi $\gamma_{d}$ maks dan $O M C$. Sehingga didapatkan nilai penurunan angka pori $(e)$ terhadap beban yang diterapkan $(p)$, dari reduksi nilai angka pori dan porositas didapatkan kecepatan pemampatan.

\section{Pembuatan Grafik Pemampatan dengan square root of time method}

Percobaan konsolidasi dilakukan dengan metode akar waktu (square root of time method) yang ditemukan oleh Taylor pada tahun 1948 (Gambar 1), hal ini didasarkan dengan beberapa ketentuan yang cocok untuk tanah gambut menurut Hardiyatmo 2010, diantaranya adalah sebagai berikut :

1. Metode akar waktu dapat melakukan pembacaan penurunan (kompresi) saat terjadi konsolidasi primer (primary consolidation) dalam periode waktu yang lebih pendek.

2. Kurva penurunan teoritis yang dihasilkan berbentuk linier sampai dengan kira-kira mencapai derajat konsolidasi $60 \%(U=60 \%)$. 
Nilai kecepatan penurunan $\left(C_{v}\right)$ dapat ditentukan dan terlihat sangat jelas berdasarkan hasil kurva pada waktu t90 (waktu yang diperlukan untuk mencapai penurunan pada derajat konsolidasi $90 \%$ $(U=90 \%)$ ) sebelum masuk pada zona konsolidasi sekunder (secondary consolidation).
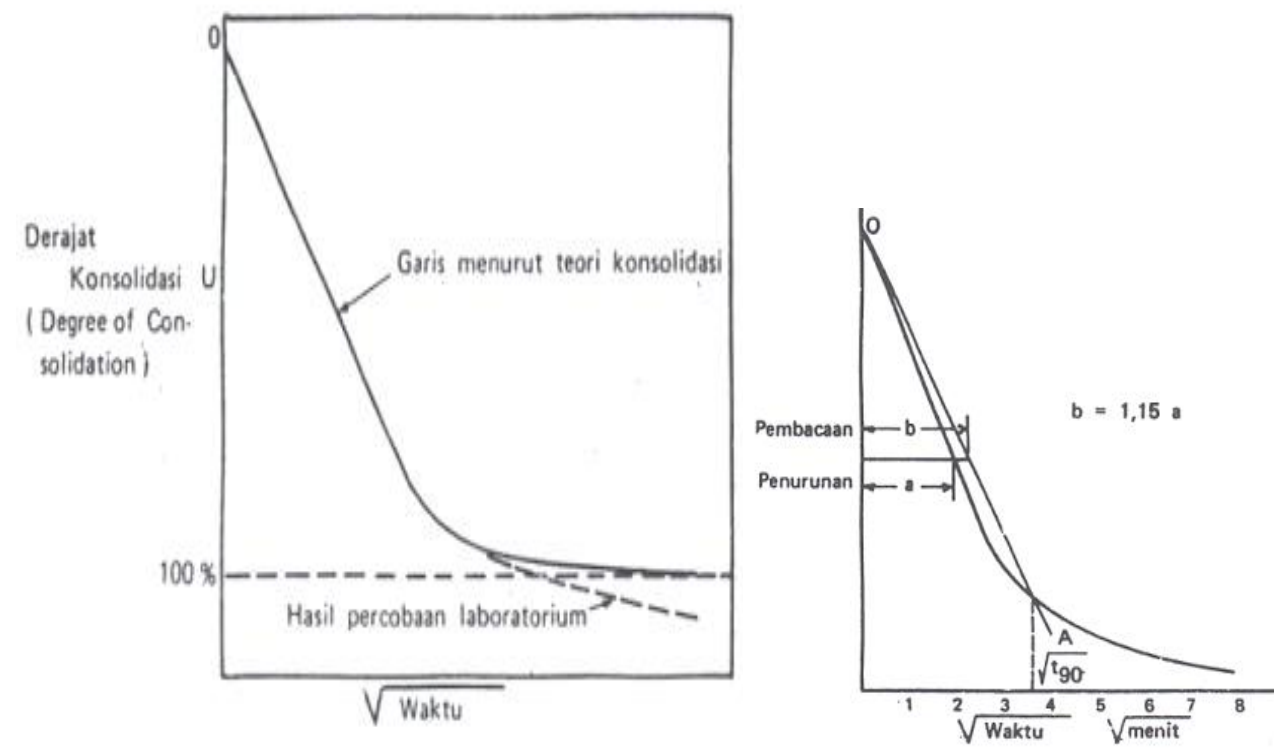

Gambar 1. Grafik konsolidasi metode akar waktu (square root of time method) (Hardiyatmo, 2010)

\section{HASIL DAN PEMBAHASAN}

Adapun hasil penelitian yang didapatkan berupa hasil pengujian konsolidasi primer dari tanah gambut pada kondisi $\gamma_{d}$ maks dan $O M C$, serta hasil grafik pemampatan tanah gambut dengan metode akar waktu (square root of time method).

\section{Hasil Pengujian Konsolidasi Primer}

Hasil pengujian konsolidasi primer didapatkan nilai penurunan angka pori $(e)$ terhadap beban yang diterapkan $(p)$ ditampilkan pada Tabel 1 dan Gambar 2. Hasil grafik pada Gambar 2 menampilkan nilai angka pori maksimum $\left(e_{m a k s}\right)$ sebelum pembebanan sebesar 2,92 dan nilai angka pori minimum $\left(e_{\min }\right)$ setelah pembebanan sebesar 1,84. Hal ini menunjukan bahwa nilai $e_{\text {maks }}$ sebesar 2,92 sebelum pembebanan memberikan kontribusi laju pemampatan yang tinggi saat diberikan beban.
Tabel 1 Pengurangan nilai angka pori akibat beban

\begin{tabular}{cc}
\hline Beban $(\boldsymbol{p})=\mathbf{k g} / \mathbf{c m}^{2}$ & Angka Pori $(\boldsymbol{e})$ \\
\hline 0 (before loading) & 2,9236 \\
0,25 (loading 1) & 2,8311 \\
0,50 (loading 2) & 2,7595 \\
1,00 (loading 3) & 2,6386 \\
2,00 (loading 4) & 2,4482 \\
4,00 (loading 5) & 2,0937 \\
\hline Beban $(\boldsymbol{p})=\mathbf{k g} / \mathbf{c m}^{2}$ & Angka Pori $(\boldsymbol{e})$ \\
\hline 8,00 (loading 6) & 1,6440 \\
2,00 (unloading 1) & 1,7285 \\
0,25 (unloading 2) & 1,8378 \\
\hline
\end{tabular}

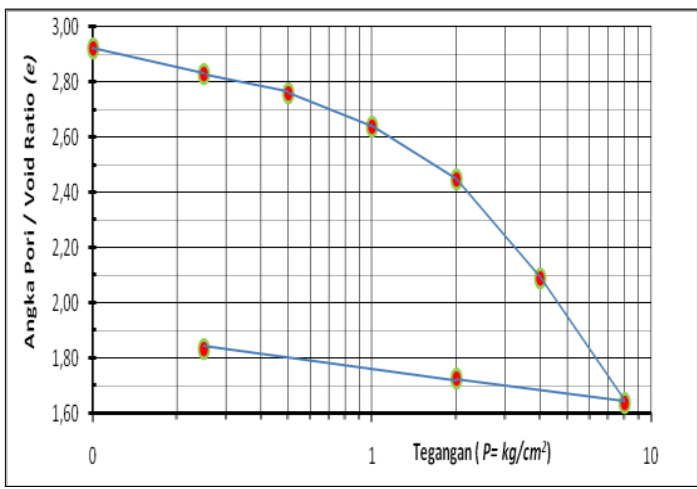

Gambar 2. Grafik hubungan antara angka pori $(e)$ terhadap beban yang diterapkan $(p)$ dari hasil uji konsolidasi primer 
Hasil Grafik Pemampatan dengan metode akar waktu (square root of time method)

Percobaan dilakukan dengan metode akar waktu (square root of time method), diperoleh berdasarkan Gambar 3 sampai Gambar 14, yang diperlihatkan melalui percobaan pembebanan ke-1 (loading 1) sampai dengan pembebanan ke-6 (loading 6) pada tegangan 0,25 $\mathrm{kg} / \mathrm{cm}^{2}$ sampai dengan tegangan 8,00 $\mathrm{kg} / \mathrm{cm}^{2}$.

\section{Hasil t90 dari Grafik Laju Pemampatan Loading 1 pada Tegangan $0,25 \mathrm{~kg} / \mathrm{cm}^{2}$}

Percobaan dilakukan dengan metode akar waktu (square root of time method), diperoleh laju pemampatan berdasarkan Gambar 3 yang diperlihatkan melalui percobaan pembebanan ke-1 (loading 1) pada tegangan $0,25 \mathrm{~kg} / \mathrm{cm}^{2}$, sedangkan untuk nilai $\sqrt{t_{90}}=1,65$ menit, maka diperoleh nilai $t_{90}=2,723$ menit.

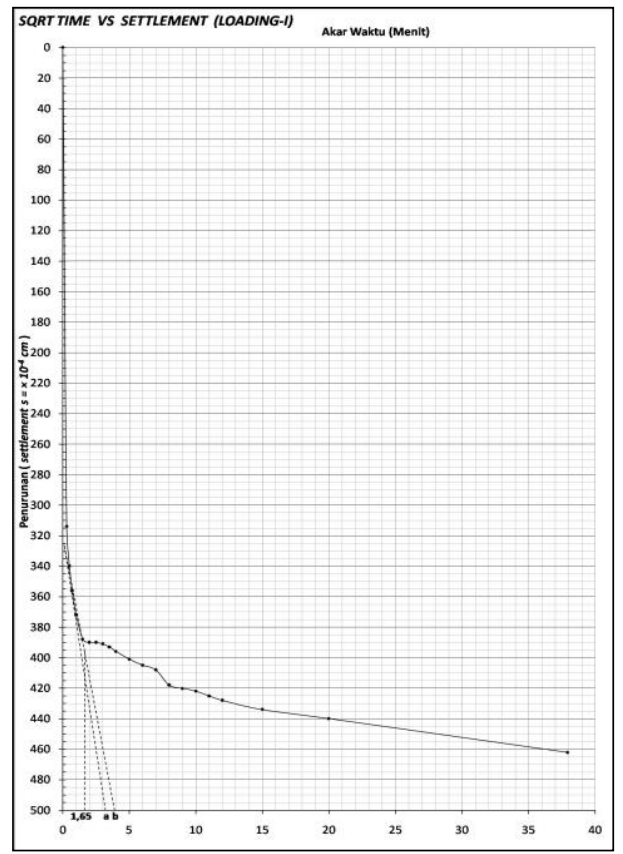

Gambar 3 Grafik hubungan penurunan dan akar waktu pada $\sigma=0,25 \mathrm{~kg} / \mathrm{cm}^{2}$ dengan nilai $\sqrt{t_{90}}=1,65$ menit
Dari grafik laju pemampatan berdasarkan Gambar 3 dapat dilihat bahwa pemampatan yang terjadi sangat tinggi dan cepat di awal waktu pembebanan diterapkan (tegangan 0,25 $\mathrm{kg} / \mathrm{cm}^{2}$ ), hal ini terlihat dari pola kurva yang dihasilkan sangat curam. Seiring berjalannya waktu, pemampatan yang terjadi semakin rendah dan lambat, kemudian pemampatan berhenti.

\section{Hasil t9o dari Grafik Laju Pemampatan Loading 2 pada Tegangan $0,50 \mathrm{~kg} / \mathrm{cm}^{2}$}

Percobaan dilakukan dengan metode akar waktu (square root of time method), diperoleh laju pemampatan berdasarkan Gambar 4 yang diperlihatkan melalui percobaan pembebanan ke-2 (loading 2) pada tegangan $0,50 \mathrm{~kg} / \mathrm{cm}^{2}$, sedangkan untuk nilai $\sqrt{t_{90}}=5,45$ menit, maka diperoleh $t_{90}=29,073$ menit.

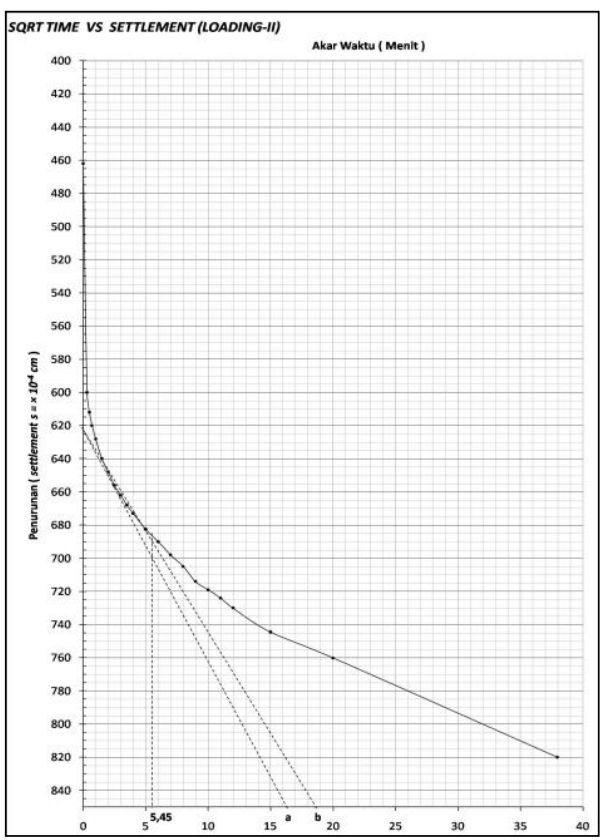

Gambar 4 Grafik hubungan penurunan dan akar waktu pada $\sigma=0,50 \mathrm{~kg} / \mathrm{cm}^{2}$ dengan nilai

$$
\sqrt{t_{90}}=5,45 \text { menit }
$$

Dari grafik laju pemampatan berdasarkan Gambar 4 dapat dilihat bahwa pemampatan yang terjadi sangat tinggi dan cepat di awal waktu 
pembebanan diterapkan (tegangan 0,50 $\mathrm{kg} / \mathrm{cm}^{2}$ ), hal ini terlihat dari pola kurva yang dihasilkan masih curam. Seiring berjalannya waktu, pemampatan yang terjadi semakin rendah dan lambat, kemudian pemampatan berhenti.

Hasil t9o dari Grafik Laju Pemampatan Loading 3 pada Tegangan $1,00 \mathrm{~kg} / \mathrm{cm}^{2}$

Percobaan dilakukan dengan metode akar waktu (square root of time method), diperoleh laju pemampatan berdasarkan Gambar 5 yang diperlihatkan melalui percobaan pembebanan ke-3 (loading 3) pada tegangan $1,00 \mathrm{~kg} / \mathrm{cm}^{2}$, sedangkan untuk nilai $\sqrt{t_{90}}=10,1$ menit, maka diperoleh nilai $t_{90}=102,01$ menit.

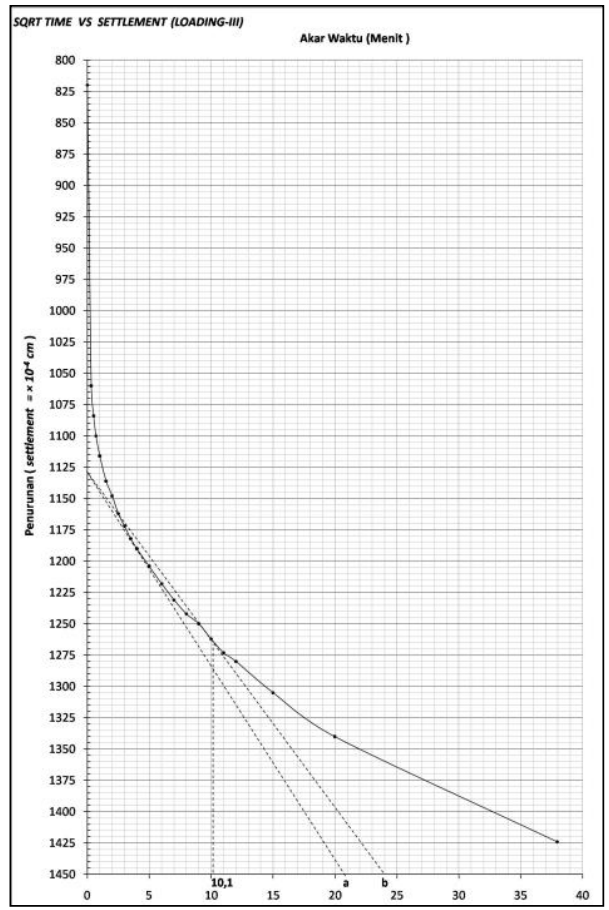

Gambar 5 Grafik hubungan penurunan dan akar waktu pada $\sigma=1,00 \mathrm{~kg} / \mathrm{cm}^{2}$ dengan nilai

$$
\sqrt{t_{90}}=10,1 \text { menit }
$$

Dari grafik laju pemampatan berdasarkan Gambar 6 dapat dilihat bahwa pemampatan terjadi sangat tinggi dan cepat di awal pembebanan diterapkan (tegangan $1,00 \mathrm{~kg} / \mathrm{cm}^{2}$ ), hal ini terlihat dari pola kurva yang dihasilkan masih curam. Seiring berjalannya waktu, pemampatan terjadi semakin rendah dan lambat, kemudian pemampatan berhenti.

Hasil t9o dari Grafik Laju Pemampatan Loading 4 pada Tegangan $2,00 \mathrm{~kg} / \mathrm{cm}^{2}$

Percobaan dilakukan dengan metode akar waktu (square root of time method), diperoleh laju pemampatan berdasarkan Gambar 6 dari percobaan pembebanan ke-4 (loading 4) pada tegangan $2,00 \mathrm{~kg} / \mathrm{cm}^{2}$, sedangkan untuk nilai $\sqrt{t_{90}}=4,85$ menit, maka diperoleh nilai $t_{90}=23,523$ menit.

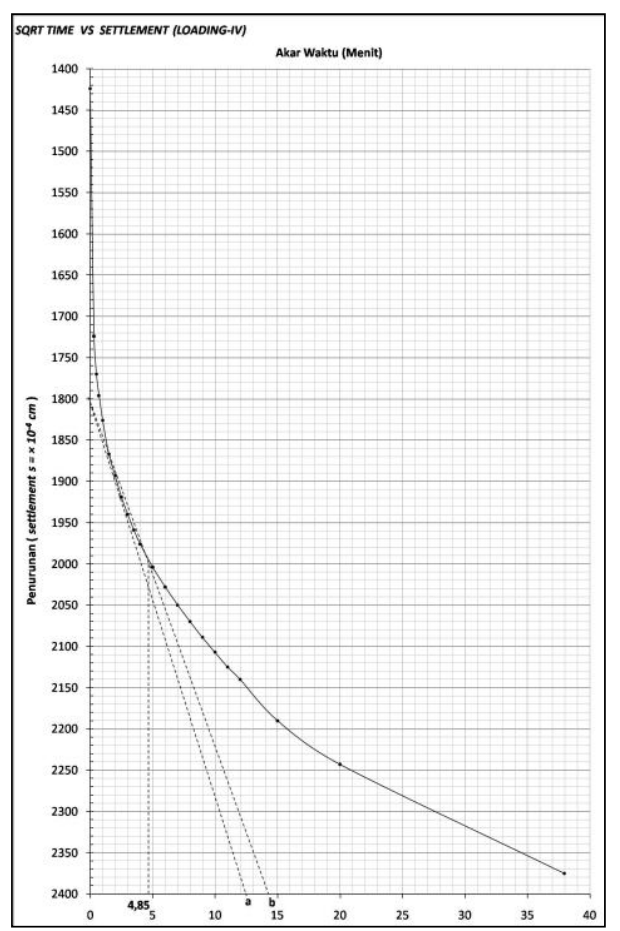

Gambar 6 Grafik hubungan penurunan dan akar waktu pada $\sigma=2,00 \mathrm{~kg} / \mathrm{cm}^{2}$ dengan nilai

$$
\sqrt{t_{90}}=4,85 \text { menit }
$$

Dari grafik laju pemampatan berdasarkan Gambar 6 dapat dilihat bahwa pemampatan terjadi sangat tinggi dan cepat di awal waktu pembebanan diterapkan (tegangan $2,00 \mathrm{~kg} / \mathrm{cm}^{2}$ ), hal ini terlihat dari pola kurva yang dihasilkan curam. Seiring berjalannya waktu, pemampatan terjadi semakin rendah dan lambat, kemudian pemampatan berhenti. 
Hasil t90 dari Grafik Laju Pemampatan Loading 5 pada Tegangan $4,00 \mathrm{~kg} / \mathrm{cm}^{2}$

Percobaan dilakukan dengan metode akar waktu (square root of time method), diperoleh laju pemampatan berdasarkan Gambar 7 yang diperlihatkan melalui percobaan pembebanan ke-5 (loading 5) pada tegangan $4,00 \mathrm{~kg} / \mathrm{cm}^{2}$, sedangkan untuk nilai $\sqrt{t_{90}}=4,00$ menit, maka diperoleh nilai $t_{90}=16$ menit.

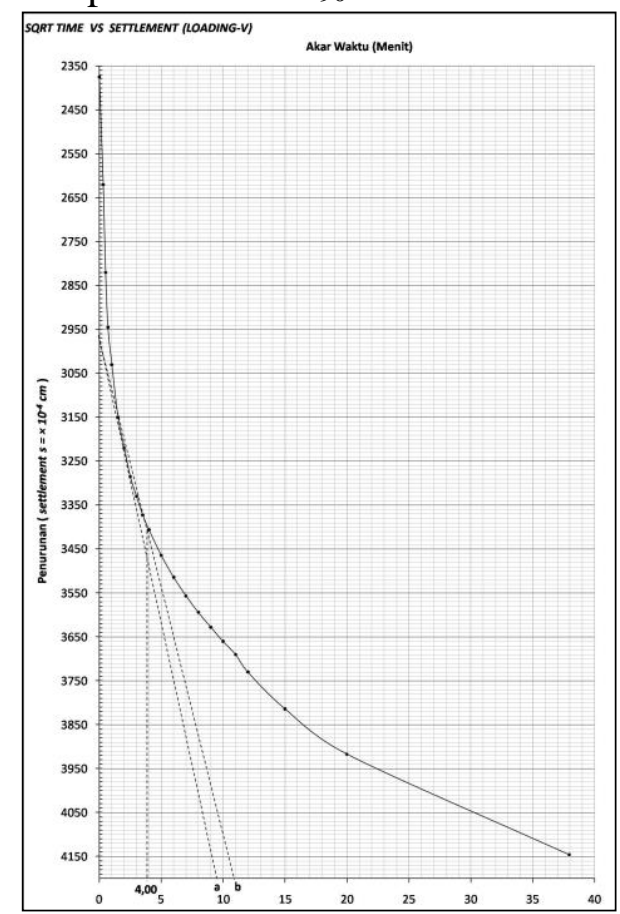

Gambar 7 Grafik hubungan penurunan dan akar waktu pada $\sigma=4,00 \mathrm{~kg} / \mathrm{cm}^{2}$ dengan nilai $\sqrt{t_{90}}=4,00$ menit

Dari grafik laju pemampatan berdasarkan Gambar 7 bahwa pemampatan yang terjadi sangat tinggi dan cepat di awal pembebanan diterapkan (tegangan $4,00 \mathrm{~kg} / \mathrm{cm}^{2}$ ), hal ini terlihat dari pola kurva yang dihasilkan curam. Seiring berjalannya waktu, pemampatan yang terjadi semakin rendah dan lambat, kemudian pemampatan berhenti.

\section{Hasil t9o dari Grafik Laju Pemampatan Loading 6 pada Tegangan $8,00 \mathrm{~kg} / \mathrm{cm}^{2}$}

Percobaan dilakukan dengan metode akar waktu (square root of time method), diperoleh laju pemampatan berdasarkan Gambar 8 yang diperlihatkan melalui percobaan pembebanan ke-6 (loading 6) pada tegangan $8,00 \mathrm{~kg} / \mathrm{cm}^{2}$, sedangkan untuk nilai $\sqrt{t_{90}}=6,00$ menit, maka diperoleh nilai $t_{90}=36$ menit.

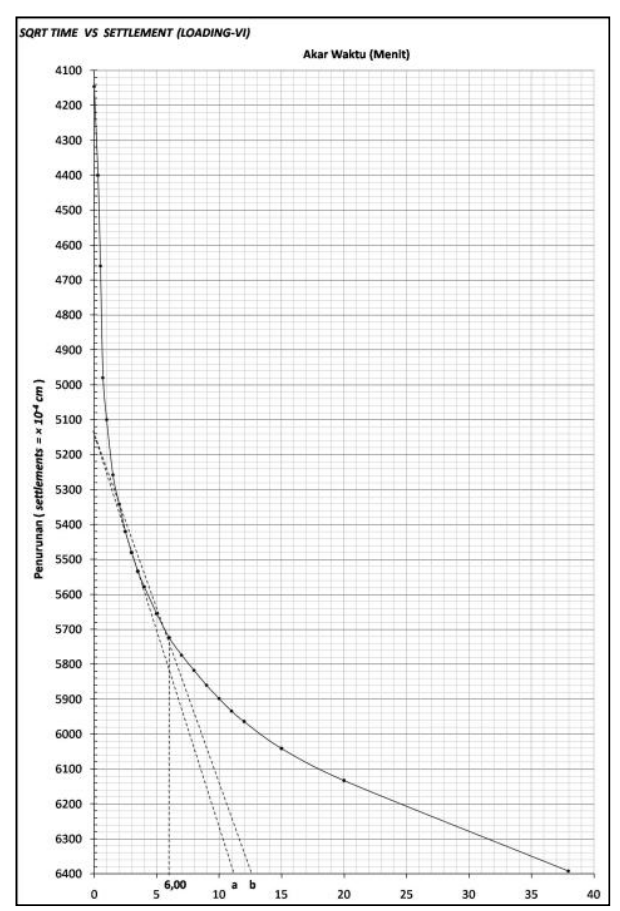

Gambar 8 Grafik hubungan penurunan dan akar waktu pada $\sigma=8,00 \mathrm{~kg} / \mathrm{cm}^{2}$ dengan nilai

$$
\sqrt{t_{90}}=6,00 \text { menit }
$$

Dari grafik laju pemampatan berdasarkan Gambar 8 dapat dilihat bahwa pemampatan yang terjadi sangat tinggi dan cepat di awal waktu pembebanan diterapkan (tegangan 8,00 $\mathrm{kg} / \mathrm{cm}^{2}$ ), hal ini terlihat dari pola kurva yang dihasilkan curam. Seiring berjalannya waktu, pemampatan yang terjadi semakin rendah dan lambat, kemudian pemampatan berhenti.

\section{Hasil Grafik Laju Pemampatan} Loading 1 - Loading 6 pada Tegangan $0,25 \mathrm{~kg} / \mathrm{cm}^{2}-8,00 \mathrm{~kg} / \mathrm{cm}^{2}$

Percobaan dilakukan dengan metode akar waktu (square root of time method), diperoleh laju pemampatan 
loading 1 - loading 6 pada tegangan 0,25 $\mathrm{kg} / \mathrm{cm}^{2}-8,00 \mathrm{~kg} / \mathrm{cm}^{2}$ dalam kondisi $\gamma_{d}$ maks $=0,449 \mathrm{gr} / \mathrm{cm} 3$ dan $O M C=95,32 \%$ (Tifani, 2015) didasarkan pada Gambar 9.

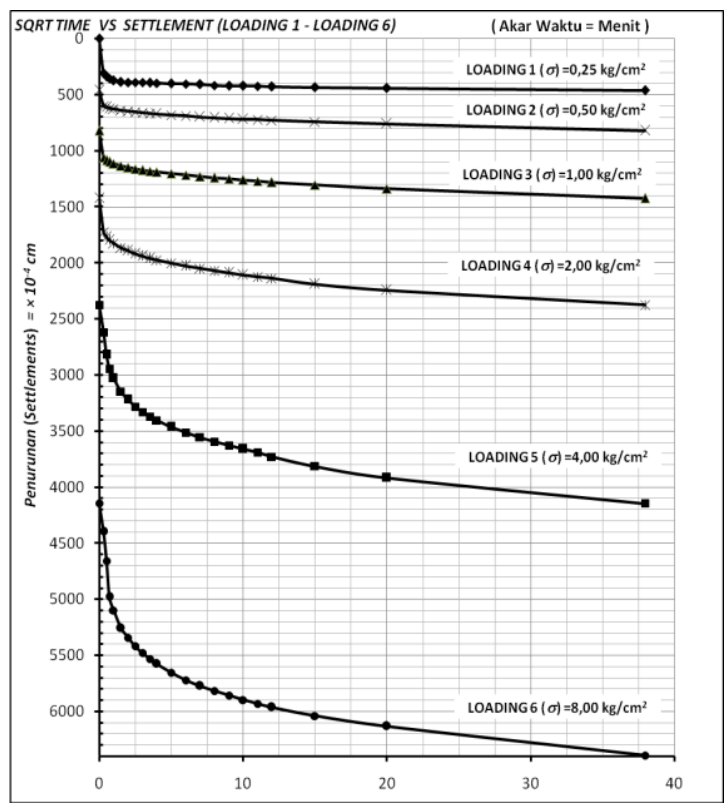

Gambar 9 Grafik hubungan penurunan dan akar waktu pada $\sigma=0,25 \mathrm{~kg} / \mathrm{cm}^{2} \mathrm{~s} / \mathrm{d} 8,00$ $\mathrm{kg} / \mathrm{cm}^{2}$

Dari grafik laju pemampatan berdasarkan Gambar 9 dapat dilihat bahwa pemampatan yang terjadi tinggi dan cepat di awal waktu pembebanan diterapkan (tegangan $0,25 \mathrm{~kg} / \mathrm{cm}^{2}$ ). Seiring dengan bertambahnya beban dilihat bahwa pemampatan yang terjadi semakin tinggi dan cepat sampai pembebanan akhir diterapkan (tegangan $8,00 \mathrm{~kg} / \mathrm{cm}^{2}$ ), hal ini menunjukan bahwa laju pemampatan yang terjadi pada tanah gambut masih sangat tinggi pada setiap pembebanan selama konsolidasi primer berlangsung.

Adapun menurut Yenni (2008) hasil kompresibilitas (pemampatan) tanah gambut dengan metode log-time diperoleh laju pemampatan loading 1 - loading 6 pada tegangan $3 \mathrm{kPa}-101 \mathrm{kPa}(0,03$ $\left.\mathrm{kg} / \mathrm{cm}^{2}-1,01 \mathrm{~kg} / \mathrm{cm}^{2}\right)$ pada kondisi variasi kadar air tertentu, dimana diambil pada nilai kadar air $140 \%$, dengan kondisi tanpa siklus setelah dipadatkan didasarkan pada Gambar 10.

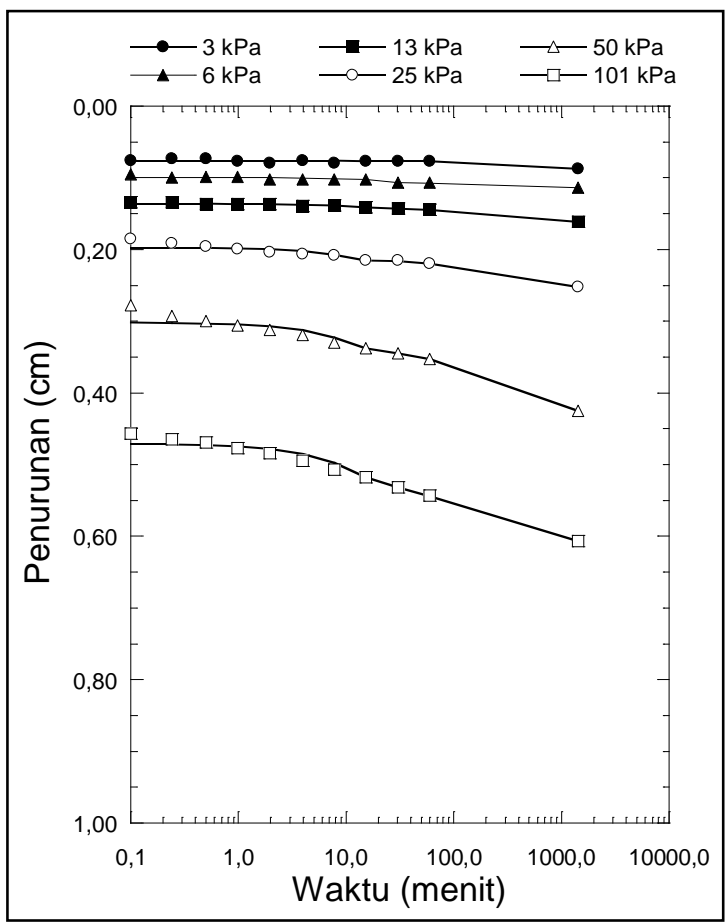

Gambar 10 Grafik hubungan penurunan dan $\log$ waktu pada $\sigma=0,03 \mathrm{~kg} / \mathrm{cm}^{2} \mathrm{~s} / \mathrm{d} 1,01$

$$
\mathrm{kg} / \mathrm{cm}^{2}
$$

Dari grafik kompresibilitas (pemampatan) berdasarkan Gambar 10 dapat dilihat bahwa pemampatan yang terjadi tinggi dan cepat di awal waktu pembebanan diterapkan (tegangan 0,03 $\mathrm{kg} / \mathrm{cm}^{2}$ ). Seiring dengan bertambahnya beban dilihat bahwa pemampatan yang terjadi semakin tinggi dan cepat sampai pembebanan akhir diterapkan (tegangan $1,01 \mathrm{~kg} / \mathrm{cm}^{2}$ ), hal ini menunjukan adanya persamaan perilaku pemampatan yang terjadi selama konsolidasi primer berlangsung baik dengan menggunakan metode metode akar waktu maupun metode log-time.

\section{KESIMPULAN}

Berdasarkan hasil pengujian konsolidasi primer dari nilai grafik hasil percobaan 
pada Gambar 3 sampai dengan 8 tersebut memberikan hasil yang sesuai dengan beberapa ketentuan Taylor (1948) dengan kesimpulan penurunan (kompresi) pada saat terjadi konsolidasi primer (primary consolidation) terjadi dalam waktu yang sangat cepat pada waktu t90 (waktu yang diperlukan untuk mencapai penurunan pada derajat konsolidasi $90 \%(\mathrm{U}=90 \%)$ ) dengan kurva yang dihasilkan berbentuk linier.

\section{DAFTAR PUSTAKA}

Hardiyatmo, H.C., 2010, Mekanika Tanah II. Yogyakarta: Gadjah Mada University Press.

H. Canakci, M. Hamed, F. Celik, W. Sidik, and F. Eviz, "Friction characteristics of organic soil with construction materials," Soils Found., vol. 56, no. 6, pp. 965-972, 2016.

N. E. Mochtar and F. E. Yulianto, "Compression Behavior of Fibrous Peat Stabilized with Admixtures of Lime $\mathrm{CaCO} 3+$ Rice Husk Ash and Lime CaCO3+Fly Ash," Int. J. Adv. Sci. Eng. Inf. Technol., vol. 8, no. 3, p. 792, Jun. 2018.

Kementrian Pertanian, Lahan Gambut Indonesia, 2nd ed. Jakarta: IAARD Press, 2016.

MacFarlane, IC., 1969, Muskeg Engineering Handbook, Canada: Muskeg Subcommittee of the NRC Associate Committee on Geotechnical Research University of Toronto Press.

Sukandarrumidi, 2009, Rekayasa Gambut, Briket Batu Bara, dan Sampah Organik. Yogyakarta: Gadjah Mada University Press.

Tifani., 2015, Kajian Perilaku Penurunan

Pondasi Tanah Gambut Akibat Prapembebanan Dan Fluktuasi
Muka Air Tanah; Inovtek, Volume 5, Nomor 1, April 2015, hlm. 194 - 83: Politeknik Negeri Bengkalis, Bengkalis

W. S. Sidik, H. Canakci, I. H. Kilic, and F. Celik, "Applicability of biocementation for organic soil and its effect on permeability," Geomech. Eng., vol. 7, no. 6, pp. 649-663, Dec. 2014.

Yenni, F., 2008. Perilaku Kompresibilitas Tanah Gambut Akibat Siklus Pembasahan dan Pengeringan Setelah Dipadatkan. Skripsi. Jakarta: Jurusan Teknik Sipil Fakultas Teknik, Universitas Indonesia. 